\title{
PENGARUH PENERAPAN METODE DISCOVERY TERHADAP KEMAMPUAN PEMECAHAN MASALAH MATEMATIKA SISWA KELAS X SMK
}

\author{
Nopikasari $^{1}$, Aty Nurdiana ${ }^{2}$, Firiana Rahmawati ${ }^{3}$ \\ STKIP PGRI Bandar Lampung ${ }^{1,2,3}$ \\ fitrianamath@gmail.com ${ }^{3}$
}

\begin{abstract}
ABSTRAK
Penelitian ini bertujuan untuk mengetahui pengaruh penerapan metode Discovery terhadap kemampuan pemecahan masalah matematika siswa kelas $\mathrm{X}$ SMK Tamansiswa Telukbetung Bandar Lampung tahun pelajaran 2018/2019. Penelitian ini merupakan penelitian eksperimen dengan pengujian hipotesis menggunakan analisis statistik sederhana dengan uji t. Pengukuran variabel menggunakan tes berbentuk uraian sebanyak lima soal yang terlebih dahulu diuji validitas dan reliabilitasnya. Populasi dalam penelitian ini adalah siswa kelas X SMK Tamansiswa Telukbetung Bandar Lampung tahun pelajaran 2018/2019. Dua kelas dijadikan sampel yaitu kelas X OTKP 1 siswa sebagai kelas eksperimen dan kelas X AKL sebagai kelas kontrol. Pengambilan sampel menggunakan teknik Cluster Random Sampling. Hasil pengujian hipotesis didapat $t_{\text {hit }}=5,38$ dan dari tabel distribusi pada taraf signifikan 5\% dengan $t_{d a f}=t_{(1-1 / 2 \alpha)}=2,00$. Dapat disimpulkan bahwa kemampuan pemecahan masalah matematika siswa kelas X SMK Tamansiswa Telukbetung Bandar Lampung akan lebih optimal dan lebih efektif jika menggunakan metode Discovery.
\end{abstract}

Kata kunci : metode Discovery, pemecahan masalah matematika

\begin{abstract}
This study aimed in determining the effect in application of the Discovery method to the mathematical problem solving ability in class X students at SMK Tamansiswa Teluk Betung Bandar Lampung in the academic year 2018/2019. This research was an experimental research with hypothesis testing by using simple statistical analysis by t-test. In measurement of variables were using a test in the form of a description of five questions that were first tested for validity and reliability. The population of this study were students of class $X$ at SMK Tamansiswa Telukbetung Bandar Lampung in the academic year 2018/2019. The two classes were as sampled: class X OTKP 1 students as the experimental class and class $\mathrm{X}$ AKL as the control class. Sampling using Cluster Random Sampling technique. The hypothesis testing results obtained tit 5.38 and from the distribution table was at a significant level of $5 \%$ with $\mathrm{t}$ dat $=$ $\mathrm{t}-120)=2.00$. It concluded that the mathematical problem solving ability in class X students at SMK Tamansiswa Telukbetung Bandar Lampung should be more optimal and effective by using the Discovery method.
\end{abstract}

Keywords : discovery method, mathematical problem solving 


\section{PENDAHULUAN}

Pembelajaran matematika merupakan kegiatan pembelajaran yang dapat menghasilkan suatu perubahan, baik menyangkut pengetahuan, keterampilan, sikap serta nilai-nilai yang diperlukan dalam kehidupan manusia. Melalui pembelajaran matematika kita dipersiapkan untuk menyesuaikan diri dengan majunya ilmu pengetahuan dan teknologi yang semakin lama semakin berkembang. Maka dapat dikatakan bahwa pembelajaran matematika merupakan suatu bekal dalam mempersiapkan generasi yang lebih maju.

Beberapa penelitian tentang kemampuan matematika ternyata di Indonesia masih banyak permasalahan mengenai pembelajaran matematika di sekolah yaitu dengan belum optimalnya kemampuan matematika tersebut. Hal tersebut disebabkan oleh upaya pengembangan kemampuan matematika di sekolah-sekolah belum merata dan belum maksimal. Ketidakmaksimalan ini dapat dilihat dari hasil jawaban siswa dalam mengerjakan soal-soal matematika, hasilnya belum memuaskan ataupun siswa kesulitan saat menghadapi soal-soal yang memerlukan kemampuan berpikir lebih.

Pada kelas $\mathrm{X}$ juga masih dijumpai berbagai permasalahan yang berakibat pada kurangnya kemampuan pemecahan masalah matematika yang diperoleh. Kurang maksimalnya kemampuan matematika siswa disebabkan dalam pembelajaran matematika siswa kurang terbiasa dengan soal-soal pemecahan masalah yang jarang diberikan dalam pembelajaran, siswa kurang aktif dalam mengikuti pelajaran, siswa sulit memahami materi yang disampaikan oleh guru, siswa terlihat pasif dan mengandalkan gurunya serta cenderung mudah menyerah tanpa menggunakan kemampuan berpikir matematikanya yang baik. Selain itu, siswa kelas X juga terkesan malas untuk mempelajari matematika karena terlalu banyak rumus dan matematika merupakan pelajaran yang dianggap sulit. Dalam pelajaran matematika guru harus menciptakan kondisi yang dapat mendorong siswa aktif dalam pembelajaran agar proses belajar-mengajar menjadi lancar.

Permasalahan matematika lainnya yaitu siswa menganggap bahwa pelajaran matematika di sekolah kurang menarik dan menyenangkan, selain itu kurangnya motivasi siswa dalam belajar yang membuat siswa sulit untuk menyenangi pelajaran matematika, yang berakibat pada pasifnya pembelajaran dan hasil belajar matematika kurang memuaskan. Maka dari itu, perlu adanya perbaikan kualitas pembelajaran matematika di sekolah.

Permasalahan-permasalahan tersebut di atas ternyata juga terjadi di kelas $\mathrm{X}$ SMK Tamansiswa Telukbetung Bandar Lampung, yang terlihat dari rendahnya jumlah siswa tuntas tes kemampuan pemecahan masalah matematika pada saat pra penelitian. Maka, perbaikan kemampuan pemecahan masalah matematika sangat diperlukan.

Polya dalam Hendriana, dkk. (2016:33) mendefinisikan pemecahan masalah merupakan usaha mencari jalan keluar dari suatu kesulitan guna mencapai suatu tujuan yang tidak begitu mudah segera dicapai. Sedangkan Lestari dan Yudhanegara (2017:84) menyatakan bahwa kemampuan pemecahan masalah adalah kemauan dalam menyelesaikan masalah tersebut.

Polya (1985:6-16) menjelaskan ada beberapa tahapan dalam kemampuan pemecahan masalah matematika, yaitu (1) memahami masalah (understanding the problem); (2) merencanakan (devising a plan); (3) melaksanakan rencana (carry out a plan); dan (4) lihatlah kembali (looking back). Dengan penjelasan sebagai berikut : 
(1) Memahami masalah (understanding the problem) yaitu untuk memecahkan suatu permasalahan seorang siswa haruslah memahami masalahnya terlebih dahulu. Tetapi jika siswa tidak memahami masalah tersebut solusi dari permasalahan tersebut hanyalah sebuah harapan bukan pemecahan. Dalam memahami masalah ini siswa dapat melakukannya dengan mengulang pertanyaan, membuat poin yang merupakan permasalahannya, menunjukkan hal-hal yang ditanyakan serta hal-hal yang diketahui dari permasalahan yang diberikan; (2) Merencanakan (devising a plan) yaitu perencanaan yang dibuat ketika kita mengetahui atau setidaknya secara garis besar memahami perhitungan, langkah-langkah untuk menyelesaikan hal-hal yang kita pahami pada langkah pertama. Sesuai dengan permasalahan yang kita buat dapat membuat perencanaan atau ide yang sesuai yang akan digunakan untuk permasalahan tersebut; (3) Melaksanakan rencana (carry out a plan) yang digunakan untuk melaksanakan rencana dalam memperoleh ide untuk menentukan solusi itu tidaklah mudah. Diperlukan pengetahuan yang memadai, kebiasaan yang baik, konsentrasi terhadap tujuan, dan semangat. Untuk menjalankan perencanaan ini sangat mudah ketika kita mempunyai kesabaran, pada langkah ini jika siswa memahami perencanaannya dengan baik maka proses melaksanakan rencana tersebut dapat berjalan dengan baik dan begitu juga sebaliknya; (4) Lihatlah kembali (looking back) yang merupakan sebuah langkah yang terjadi jika siswa telah menemukan solusi dari permasalahannya dan menuliskan argumen serta alasannya secara lengkap dalam bukunya serta memahami cara lainnya itu artinya mereka telah mencapai solusi yang sempuna dan telah melakukan pengecekan terhadap langkahnya.

Suherman dalam Hendriana, dkk. (2016:38) menyatakan bahwa indikator pemecahan masalah meliputi: Mengamati; mengidentifikasi; memahami; merencanakan; menduga; menganalisis; mencoba; menginterprestasi; menemukan; menggeneralisasi; meninjau kembali.

Sedangkan menurut Lestari dan Yudhanegara (2017:85) indikator kemampuan pemecahan masalah, yaitu (1) mengidentifikasi unsur-unsur yang diperlukan; (2) merumuskan dan menyusul model masalah; (3) menerapkan metode penyelesaian; dan (4) menjelaskan hasil dari penyelesaian masalah.

Untuk mengembangkan kemampuan pemecahan masalah matematika di atas, dapat diterapkan beberapa metode pembelajaran salah satunya metode Discovery. Metode Discovery merupakan suatu metode pembelajaran yang mengajarkan keterampilan siswa serta memajukan cara belajar siswa aktif untuk mencapai tujuan belajarnya. Dalam metode Discovery siswa ditempatkan sebagai subyek belajar yang memiliki pengetahuan dan keterampilan yang berbeda serta mendorong siswa untuk mengembangkan kemampuan yang dimilikinya.

Suryosubroto (Hamzah dan Muhlisrarini, 2014:247) mengungkapkan bahwa metode Discovery diartikan sebagai suatu prosedur mengajar yang mementingkan pengajaran perseorangan, manipulasi objek dan lain-lain, sebelum sampai kepada generalisasi. Sedangkan menurut Djamarah (Afandi dkk, 2013:98), Discovery adalah belajar mencari dan menemukan sendiri. Dalam sistem belajar-mengajar ini guru menyajikan bahan pelajaran yang tidak berbentuk final, tetapi anak didik diberi peluang untuk mencari dan menemukan sendiri dengan menggunakan teknik pendekatan pemecahan masalah.

Menurut Sani (2014:97) metode Discovery merupakan metode pembalajaran kognitif yang menuntut guru lebih kreatif menciptakan situasi yang dapat membuat peserta didik belajar aktif menemukan pengetahuan sendiri. Selain itu menurut 
Ruseffendi (Gusmania dan Marlita, 2016:153) metode Discovery merupakan suatu metode mengajar yang mengatur pengajaran, sehingga anak memperoleh pengetahuan baru yang sebelumnya tidak tahu menjadi tahu. Sedangkan menurut Jarwan (2018:78) Discovery adalah metode pembelajaran yang menuntun siswa untuk mengenal dan merumuskan masalah kemudian menguji hipotesis dengan penyelidikan sehingga data ditarik kesimpulan dan menyajikannya.

Kemudian, langkah-langkah dalam metode Discovery menurut Afandi, dkk (2013 : 100) adalah (1) menemukan kebutuhan siswa; (2) pemilihan pendahuluan, konsep dan kesimpulan pengetahuan; (3) pemilihan bahan ajar dan permasalahan; (4) guru memperjelas permasalahan yang akan dipelajari; (5) menyiapkan alat yang diperlukan dan setting kelas; (6) mengecek pengertian siswa terhadap masalah yang diberikan; (7) siswa diberi kesempatan untuk melakukan penemuan; (8) guru membantu siswa dalam proses penemuan jika diperlukan oleh siswa; (9) siswa menganalisis sendiri dengan pertanyaan dan identifikasi proses; (10) merangsang interaksi siswa dengan siswa; (11) memberikan apresiasi kepada siswa yang giat melakukan penemuan; dan (12) membantu siswa dalam menarik kesimpulan dan merumuskan prinsip hasil temuannya.

Selain itu, langkah-langkah dalam metode Discovery menurut Sani (2014:98), yaitu (1) guru menjelaskan tujuan pembelajaran; (2) guru membagi petunjuk praktikum/eksperimen; (3) peserta didik melaksanakan eksperimen di bawah pengawasan guru; (4) guru menunjukkan gejala yang diamati; dan (5) peserta didik menyimpulkan hasil eksperimen.

Salah satu kajian relevan yang dijadikan pedoman dalam penelitian ini adalah penelitian eksperimen semu yang dilakukan oleh Gusmania dan Marlita (2016) tentang Pengaruh Metode Discovery Learning Terhadap Kemampuan Pemecahan Masalah Matematis Siswa Kelas X SMA Negeri 5 Batam Tahun Pelajaran 2014/2015. Didapatkan rata-rata kemampuan pemecahan masalah matematika siswa tergolong baik pada skor 77,04 dengan hasil analisis data uji one sample t-test pada $\mu=75$ diperoleh $t=12,686$ yang artinya metode Discovery Learning efektif terhadap kemampuan pemecahan masalah matematika siswa.

Berdasarkan latar belakang di atas, maka tujuan dari penelitian ini adalah untuk mengetahui pengaruh penerapan metode Discovery terhadap kemampuan pemecahan masalah matematika siswa kelas X semester genap SMK Tamansiswa Telukbetung Bandar Lampung Tahun Pelajaran 2018/2019. Sedangkan langkah-langkah pembelajaran Discovery yang digunakan dalam penelitian ini adalah menurut Afandi, dkk (2013:100) karena langkah tersebut dianggap lebih efektif serta sesuai dengan kondisi siswa kelas X SMK Taman Siswa Teluk Betung.

\section{METODE}

Pelaksanaan penelitian ini menggunakan metode eksperimen. Variabel dalam penelitian ini terdiri dari metode pembelajaran Discovery dan kemampuan pemecahan masalah matematika.

Penelitian ini dilaksanakan di SMK Tamansiswa Telukbetung Bandar Lampung pada semester genap tahun pelajaran 2018/2019 pada materi fungsi. Populasinya adalah siswa kelas X. Total populasi 185 siswa yang tersebar dalam 6 kelas, yaitu X AKL, X OTKP 1, X OTKP 2, X TKJ 1, X TKJ 2, dan X TKJ 3. 
Teknik Cluster Random Sampling dipilih untuk menentukan kelas eksperimen dan kelas kontrol dengan cara mengundi seluruh kelas $\mathrm{X}$ yang kemudian didapat 2 kelas yang dianggap mewakili kelas lainnya karena mengingat seluruh kelas memiliki kemampuan yang sama. Lalu, dari 2 kelas tersebut diundi lagi untuk menentukan kelas eksperimen dan kelas kontrol. Kelas yang pertama keluar adalah kelas eksperimen dan yang satunya sebagai kelas kontrol, sehingga kelas X OTKP 1 dan X AKL terpilih sebagai kelas eksperimen dan kelas kontrol.

Pada penelitian ini pengukuran variabel menggunakan tes yang terdiri dari lima soal uraian dengan pemberian skor atau bobot nilai untuk setiap soal sesuai rubrik penskoran yang mengacu pada indikator kemampuan pemecahan masalah matematika yang telah ditetapkan. Kemudian, nilai dikonversi pada rentang $0 \leq x \leq$ 100 dan dijadikan data penelitian. Rubrik penskoran kemampuan pemecahan masalah matematika mengacu pada Tangio (2015: 7). Sebelum penelitian, soal tes diuji validitas dan reliabilitas terlebih dahulu agar menjadi instrumen yang baik dan benar.

Teknik analisis data yang digunakan dalam penelitian ini adalah sebagai berikut: (1) menentukan rata-rata skor dan simpangan baku, (2) uji normalitas, (3) uji homogenitas, dan (4) uji hipotesis. Dengan taraf nyata $(\alpha)=5 \%$, uji normalitas yang digunakan adalah $\chi^{2}$ dan uji homogenitas yang digunakan adalah uji kesamaan dua varians. Sedangkan untuk uji hipotesis dalam taraf nyata $(\alpha)=5 \%$ adalah $t_{\text {test }}$ untuk data normal dan homogen (Sudjana, 2005:239), $t^{\prime}$ untuk data normal tapi tidak homogen (Sudjana, 2005:227).

\section{HASIL DAN PEMBAHASAN}

Pelaksanaan penelitian berawal dari pertengahan bulan Januari hingga Februari 2019 atau pada semester genap di kelas X SMK Tamansiswa Telukbetung Bandar Lampung. Satu kelas sebagai kelas eksperimen yang diterapkan metode Discovery dan satu kelas sebagai kelas kontrol (pembanding) yang diterapkan metode konvensional dengan masing-masing kelas berjumlah 27 siswa.

Keberhasilan suatu proses pembelajaran dipengaruhi oleh penggunaan metode pembelajaran yang tepat, salah satunya yaitu metode Discovery. Pada penelitian sebelumnya, metode Discovery pada proses pembelajaran memberikan dampak positif terhadap siswa dimana siswa diarahkan untuk terlibat langsung dalam penemuan sehingga membuat siswa lebih aktif dan kreatif dalam pembelajaran.

Sesuai dengan tujuan awal yaitu menuntun siswa untuk melakukan penemuan, metode Discovery memberi kesempatan kepada siswa untuk memahami sendiri materi yang sedang dipelajari, sehingga siswa lebih mudah mengingat materi pelajaran karena siswa memperoleh pengetahuan konsep materi tersebut dari penemuannya sendiri. Siswa dituntut aktif untuk menemukan sendiri suatu konsep dari materi yang sedang dipelajari sedangkan guru hanya membimbing.

Dalam pelaksanaan penelitian ini, siswa di kelas eksperimen dibagi menjadi beberapa kelompok dan mendapat lembar kerja peserta didik (LKPD) yang di dalamnya terdapat masalah yang harus diselesaikan oleh kelompoknya. Siswa diharapkan dapat menyelesaikan masalah yang diberikan dengan melakukan penemuan sendiri. Kegiatan siswa di setiap pertemuan menekankan pada pemecahan masalah matematika secara tertulis. Sebelum diterapkan metode Discovery, siswa terlebih dahulu dijelaskan bagaimana langkah-langkahnya. Pertemuan pertama, guru masih memberikan arahan pada siswa bagaimana langkah-langkah atau prosedur 
Discovery, guru menjelaskan bagaimana mengidentifikasi permasalahan, memahami masalah yang diberikan, menyeleksi bahan dalam menyelesaikan masalah, membantu siswa dalam self analysis serta merangsang terjadinya interaksi antar siswa dalam memahami konsep dari permasalahan yang diberikan dan menarik kesimpulan, sehingga siswa lebih paham dan terbiasa dengan metode ini. Pertemuan kedua siswa mulai sedikit terbiasa dengan metode Discovery meskipun harus diingatkan kembali pada awal pembelajaran mengenai langkah-langkah metode ini. Sebagian siswa masih terkendala saat menyeleksi bahan-bahan untuk menyelesaikan permasalahan yang diberikan terutama bagi siswa berkemampuan rendah, disini guru memberikan arahan kepada siswa dalam kelompoknya untuk saling bekerjasama membantu menjelaskan kepada teman yang kesulitan dalam menyelesaikan masalahnya dengan begitu siswa bisa lebih interaktif satu sama lain dan membiasakan siswa dalam melakukan self analysis atau penemuan secara mandiri. Pertemuan selanjutnya setelah siswa mengetahui langkah-langkah Discovery dan memahaminya siswa mulai terbiasa dengan metode ini, pembelajaran mulai aktif dan mulai terlihat kerja sama yang baik antar anggota kelompok dalam mengerjakan lembar kerja siswa.

Dilihat dari hasil pengamatan pada penerapan metode Discovery terhadap kemampuan pemecahan masalah matematika di kelas eksperimen, siswa sangat antusias dalam melakukan self analysis atau penemuan secara mandiri, siswa belajar menggunakan kemampuannya sendiri untuk memahami, memecahkan dan menyelesaikan masalah berdasarkan kemampuan masing-masing serta siswa memperoleh konsep dari permasalahan yang diberikan dan mampu menarik kesimpulan sehingga dalam proses pembelajaran siswa dapat memahami materi pelajaran dengan caranya sendiri dan sesuai dengan tujuan metode Discovery yaitu penemuan secara mandiri. Sedangkan dilihat dari hasil lembar kerja peserta didik, setelah melakukan self analysis atau penemuan secara mandiri siswa mampu menyelesaikan dan menjawab soal-soal pemecahan masalah yang diberikan oleh guru dengan hasil yang maksimal.

Berbeda dengan kelas eksperimen, pada kelas kontrol yang tidak diterapkan metode Discovery, kegiatan belajar berlangsung seperti biasa dan sesuai dengan kurikulum yang diterapkan di sekolah tersebut. Pada kelas kontrol diterapkan metode konvensional dalam pembelajarannya. Pada setiap pertemuan belum terpusat pada siswa, guru masih berperan secara aktif dalam menyajikan materi di dalam kelas, sehingga mengakibatkan kurangnya kemampuan pemecahan masalah matematika siswa.

Tabel 1. Sebaran data kemampuan pemecahan masalah matematika siswa

\begin{tabular}{lcc}
\hline \multicolumn{1}{c}{ Keterangan } & Kelas eksperimen & Kelas kontrol \\
\hline Jumlah siswa & 27 & 27 \\
Nilai tertinggi & 100 & 85 \\
Nilai terendah & 65 & 44 \\
Rata-rata & 81,41 & 66,52 \\
Median & 83 & 65 \\
Modus & 73 & 75 \\
Varians & 82,4 & 128,03 \\
Simpangan baku & 9,08 & 11,32 \\
\hline
\end{tabular}


Berdasarkan sebaran tes tertulis dengan jumlah 5 soal uraian diperoleh data untuk masing-masing kelas sebagaimana terlihat dalam tabel di atas, menunjukkan adanya perbedaan hasil tes kemampuan pemecahan masalah matematika antara siswa kelas eksperimen yang menggunakan metode Discovery dengan siswa kelas kontrol yang menggunakan metode konvensional.

Berdasarkan sebaran data kelas eksperimen, diketahui rata-rata siswa $(81,41)$ telah berada di kategori sangat baik. Sedangkan untuk kelas kontrol, didapatkan ratarata siswa $(66,52)$ termasuk dalam kategori baik. Dengan demikian, dapat disimpulkan bahwa pembelajaran yang dilaksanakan telah berjalan dengan baik.

Berdasarkan tabel 1 di atas, nilai-nilai yang diperoleh dari hasil tes menunjukkan adanya perbedaan kemampuan pemecahan masalah matematika antara siswa kelas eksperimen yang menggunakan metode Discovery dengan siswa kelas kontrol yang menggunakan metode konvensional.

Data-data yang telah diperoleh diolah untuk pengujian hipotesis. Namun, sebelum dilakukan uji hipotesis, terlebih dahulu dilakukan uji normalitas dan uji homogenitas sebagai uji persyaratan.

Tabel 2. Uji normalitas kelas eksperimen dan kelas kontrol

\begin{tabular}{lccc}
\hline \multicolumn{1}{c}{ Kelas } & $L_{0}$ & $L_{\text {tabel }}$ & Keterangan \\
\hline Eksperimen & 0,1288 & 0,1682 & Normal \\
Kontrol & 0,0861 & 0,1682 & Normal \\
\hline
\end{tabular}

Berdasarkan hasil uji normalitas data, dengan menggunakan Uji Liliefors pada taraf nyata $(\alpha)=5 \%$ didapatkan $L_{\text {tabel }}=0,1682$. Kemudian, untuk kelas eksperimen diperoleh $L_{0}=0,1288$ dan kelas kontrol diperoleh $L_{0}=0,0861$. Dengan kriteria uji, tolak Ho jika $L_{0}>L_{\text {tabel }}$. Ternyata dari data diperoleh $L_{0}$ kedua kelas kurang dari $L_{\text {tabel }}$, maka data kedua kelas berasal dari populasi yang berdistribusi normal.

Tabel 3. Uji homogenitas varians kelas eksperimen dan kelas kontrol

\begin{tabular}{lcccc}
\hline \multicolumn{1}{c}{ Kelas } & $\mathrm{n}$ & $F_{\text {hitung }}$ & $F_{\text {tabel }}$ & Keterangan \\
\cline { 1 - 2 } Eksperimen & 27 & \multirow{2}{*}{1,55} & 1,93 & Homogen \\
\cline { 1 - 4 } Kontrol & 27 & & & \\
\hline
\end{tabular}

Berdasarkan tabel 3, pada taraf nyata $(\alpha)=5 \%$ diperoleh $F_{\text {tabel }}=1,93$ dan $F_{\text {hitung }}=1,55$. Berdasarkan kriteria uji, tolak Ho jika $F_{\text {hitung }}>F_{\text {tabel }}$. Dengan demikian, Ho diterima atau dapat disimpulkan kedua data mempunyai varians yang sama.

Mengingat fakta bahwa setelah uji normalitas dan uji homogenitas, didapatkan kedua data normal dan homogen, maka uji hipotesis kesamaan dua rata-rata yang digunakan adalah uji t. 
Tabel 4. Uji hipotesis kesamaan dua rata-rata

\begin{tabular}{lccccccc}
\hline \multicolumn{1}{c}{ Kelas } & $\mathrm{n}$ & $\bar{x}$ & $s^{2}$ & $S^{2}$ & $t_{\text {hitung }}$ & $t_{\text {tabel }}$ & Keterangan \\
\hline Eksperimen & 27 & 81,40 & 82,4 & \multirow{2}{*}{10,26} & 5,38 & 2,00 & \multirow{2}{*}{ Tidak sama } \\
\hline Kontrol & 27 & 66,52 & 128,03 & & &
\end{tabular}

Berdasarkan hasil perhitungan lengkap yang menggunakan uji-t pada taraf nyata $(\alpha)=5 \%$ diperoleh $t_{\text {tabel }}=2,00$ dan $t_{\text {hitung }}=5,38$. Dengan kriteria uji, terima Ho jika $-t_{(1-1 / 2 \alpha)}<t_{\text {hitung }}<t_{(1-1 / 2 \alpha)}$. Karena $t_{\text {hitung }}>t_{\text {tabel }}$ yaitu $5,37>2,00$, maka dapat disimpulkan Ho ditolak dan Ha diterima yang berarti ratarata kemampuan pemecahan masalah matematika siswa yang diterapkan metode Discovery tidak sama dengan rata-rata kemampuan pemecahan masalah matematika siswa yang diterapkan pembelajaran konvensional pada siswa kelas X SMK Tamansiswa Telukbetung Bandar Lampung tahun pelajaran 2018/2019.

Berdasarkan hasil penelitian dan analisis data yang telah dilakukan, diperoleh gambaran umum tentang pengaruh metode Discovery terhadap kemampuan pemecahan masalah matematika siswa kelas X SMK Tamansiswa Telukbetung Bandar Lampung tahun pelajaran 2018/2019.

Beberapa penelitian lainnya yang mendukung penelitian ini, yaitu penelitian Marantika, dkk (2015) dan Anggreini (2018) yang juga menyimpulkan bahwa metode Discovery dapat meningkatkan kemampuan pemecahan masalah matematika siswa.

\section{SIMPULAN DAN SARAN}

Berdasarkan hasil penelitian yang telah diuraikan di atas, dapat disimpulkan bahwa, "Ada pengaruh penggunaan metode Discovery terhadap kemampuan pemecahan masalah matematika siswa kelas X SMK Tamansiswa Telukbetung Bandar Lampung tahun pelajaran 2018/2019“ dengan rata-rata kemampuan pemecahan masalah matematika siswa yang diterapkan metode Discovery lebih tinggi dari rata-rata kelas yang diterapkan pembelajaran konvensional.

Sebaiknya dalam kegiatan pembelajaran digunakan metode atau model pembelajaran yang tepat khususnya metode Discovery untuk meningkatkan kemampuan pemecahan masalah matematika siswa, sehingga siswa bisa lebih aktif dalam proses pembelajaran dan dapat memahami konsep materi pelajaran yang diberikan dengan optimal.

\section{DAFTAR PUSTAKA}

Afandi, dkk. 2013. Model dan Metode Pembelajaran di Sekolah. Semarang: Unissula Press.

Anggreini, R.D. 2018. Pengaruh Pembelajaran Discovery Learning Terhadap Kemampuan Pemecahan Masalah Matematis Siswa (Studi pada Siswa Kelas VIII Semester Genap SMP Negeri 5 Bandar Lampung Tahun Pelajaran 2017/2018). Skripsi tidak diterbitkan. Bandar Lampung: Universitas Lampung. [Online]. Tersedia: http://digilib.unila.ac.id/31884/3/SKRIPSI\%20TANPA\%20 BAB\%20PEMBAHASAN.pdf. 
Gusmania, Y. dan Marlita. 2016. Pengaruh Metode Discovery Learning Terhadap Kemampuan Pemecahan Masalah Matematis Siswa Kelas X SMAN 5 Batam Tahun Pelajaran 2014/2015. Jurnal Pythagoras, Vol. 5(2) : 151-157.

Hamzah, A. dan Muhlisrarini. 2014. Perencanaan dan Strategi Pembelajaran Matematika. Jakarta: PT Raja Grafindo Persada.

Hendriana, dkk. 2016. Hard Skills dan Soft Skills Matematika Siswa. Bandung: STKIP Siliwangi Press.

Jarwan. 2018. Pengaruh Discovery Learning Terhadap Kemampuan Pemecahan Masalah dan Komunikasi Matematis Siswa. Jurnal Penelitian Matematika dan Pendidikan Matematika Proximal, Vol. 1 (2) : 77-89.

Lestari, K.E. dan Yudhanegara, M.R. 2017. Penelitian Pendidikan Matematika. Bandung: PT Refika Aditama.

Marantika, A., Handayani, T., dan Putri, A.D. 2015. Pengaruh Metode Discovery Learning Terhadap Kemampuan Pemecahan Masalah Matematika Siswa Pada Pembelajaran Matematika di SMP Pelita Palembang. Jurnal Pendidikan Matematika RAFA, Vol.1(2) : 161-183.

Polya, G. 1985. How To Solve it second edition. New Jersey: Princeton University Press.

Sani, A.R. 2014. Pembelajaran Saintifik untuk Implementasi Kurikulum 2013. Jakarta: Bumi Aksara.

Sudjana. 2005. Metoda Statistika. Bandung: Tarsito.

Tangio, N. F. 2015. Deskripsi Kemampuan Pemecahan Masalah Matematika Pada Materi Soal Cerita Penjumlahan dan Pengurangan Bilangan Bulat di Kelas VII SMP Negeri 1 Tapa. Jurnal Pendidikan Matematika, Vol. 1(1) : 1-14. 